石油技術協会誌 第 64 巻 第 1 号 (平成11年1月)

JOURNAL OF THE JAPANESE ASSOCIATION FOR PETROLEUM TECHNOLOGY

VOL. 64, NO. 1 (Jan., 1999)

$\overline{\text { 総 説 }}$

\title{
$\mathrm{K}-\mathrm{Ar},{ }^{40} \mathrm{Ar} /{ }^{39} \mathrm{Ar}$ 法による第三紀火山岩の \\ 年代測定の現状と将来*
}

$$
\text { 宇都 浩三**.石塚 治** }
$$

(Received September 24, 1998; accepted November 26, 1998)

\section{The current state and the future of $\mathrm{K}-\mathrm{Ar}$ and ${ }^{40} \mathrm{Ar} /{ }^{39} \mathrm{Ar}$ dating of volcanic rocks}

\author{
Kozo Uto and Osamu Ishizuka
}

\begin{abstract}
Current situation and future possibility of the $\mathrm{K}$-Ar and ${ }^{40} \mathrm{Ar} /{ }^{39} \mathrm{Ar}$ dating methods are reviewed focusing their utilization to the Tertiary volcanic rocks. As Tertiary volcanic rocks in general are not completely free from weathering and alteration, special attention should be made in choosing appropriate samples for age analyses. $\mathrm{K}-\mathrm{Ar}$ and ${ }^{40} \mathrm{Ar} /{ }^{39} \mathrm{Ar}$ analytical results are shown for two contemporaneous rocks of Middle Miocene age, one is a porphyritic intrusive rock with holocrystalline groundmass and the other is an extrusive lava with glassy groundmass. The former gives concordant $\mathrm{K}-\mathrm{Ar}$ and ${ }^{40} \mathrm{Ar} /{ }^{39} \mathrm{Ar}$ ages, while the latter shows considerably younger $\mathrm{K}-\mathrm{Ar}$ and ${ }^{40} \mathrm{Ar} /{ }^{39} \mathrm{Ar}$ total gas ages with the obviously disturbed ${ }^{40} \mathrm{Ar} /{ }^{39} \mathrm{Ar}$ age spectra in the low temperature fractions. These results suggest that holocrystalline rocks are preferable to glassy rocks in $\mathrm{K}-\mathrm{Ar}$ and ${ }^{40} \mathrm{Ar} /{ }^{39} \mathrm{Ar}$ dating, because glass tends to easily loose the accumulated radiogenic ${ }^{40} \mathrm{Ar}$ not only by decomposition but also by hydration. Accurate and precise age determinations can be achieved by the ${ }^{40} \mathrm{Ar} /{ }^{39} \mathrm{Ar}$ incremental heating experiments along with the age spectrum and isochron interpretations. Total fusion ${ }^{40} \mathrm{Ar} /{ }^{39} \mathrm{Ar}$ dating for single to a few grains of fresh $\mathrm{K}$-bearing phenocrysts like biotite, sanidine and plagioclase is also useful in knowing the ages for glassy and/ or altered rocks. Multiple analyses on such mineral separates ensure the reproducibility of the analyses and reduce the analytical uncertainty by statistical treatments. Systematic ${ }^{40} \mathrm{Ar} /{ }^{39} \mathrm{Ar}$ studies are now underway to construct the accurate and precise tectonic history of the Japanese island arc.
\end{abstract}

Key words : $\mathrm{K}$-Ar dating, ${ }^{40} \mathrm{Ar} /{ }^{39} \mathrm{Ar}$ dating, review, Tertiary volcanism

\section{1.はじめに}

$\mathrm{K}-\mathrm{Ar}$, フィッショントラック法などによる火山岩の放

*平成 10 年 6 月 2 日，平成 10 年度石油技術協会春季講演会地 質・探鉱部門シンポジゥム「年代層序の多様化と石油探鉱へ の応用」にて講演 This paper was presented at the 1998 JAPT Geology and Exploration Symposium entitled "Diversified chronostratigraphic tools and their application to petroleum exploration" held in Sapporo, Hokkaido, Japan, June 2, 1998.

**地質調查所地殼化学部 Geochemistry Department, Geological Survey of Japan

Copyright (C) 1999, JAPT
射年代測定は，火成活動史の解明だけでなく，生層序の 確立, テクトニクス解明, 環境変動解明など幅広い地質 学的問題解決に有用である。そのため, 大学や研究所な よ゙の年代測定研究機関のみならず商業的測定機関により 出された年代值が, 学会誌, 報告書類などで広く流通し ている。商業的测定機関による年代値を用いた論文, 報 告類の場合, 年代測定を依頼し公表する人の圧倒的多数 が，自身で年代測定をした経験のない人であり，測定試 料の吟味, 測定結果の解釈の点で, 必ずしも適切な判断 がなされているとは言い難いことが少なからず認められ る。放射年代は，さまざまな仮定を元に計算される物理 学的年代であるにもかかわらず, 得られる年代を無批判 
に地質学的に意味のある年代と断定する議論すらある。 特に, $\mathrm{K}-\mathrm{Ar}$ 年代, フィッショントラック年代の場合, 3 個以上の試料がアイソクロンを形成するか否かで， あ る程度年代値の意味を議論できる $\mathrm{Rb}-\mathrm{Sr}, \mathrm{Nd}-\mathrm{Sm}$ 年代 などと違い，1 個の試料で必ず 1 つの年代が得られるわ けで, 得られた年代值の地質学的解釈においては, 年代 測定法の原理や問題点についての十分な知識が必要とさ れる。本総説においては, 第三紀火山岩への応用に限定 $し て, \mathrm{~K}-\mathrm{Ar}$ 年代測定法の原理, 注意すべき問題点など を紹介し，レーザ加熱法による ${ }^{40} \mathrm{Ar} /{ }^{39} \mathrm{Ar}$ 年代測定法の 現状と将来について概観する。なお， K-Ar, ${ }^{40} \mathrm{Ar} /{ }^{39} \mathrm{Ar}$ 法の原理, 概要, 応用の全般については, すでに兼岡 (1988 a, 1988 b), 柴田 (1985), 板谷·長尾 (1988), 宇都 (1993，1996), 宇都・石塚（1996）などの和文の 総説が，また英文では Dalrymple and Lanphere (1969), McDougall and Harrison (1988) の教科書があ るので, 参考にされたい。

\section{2. $\mathrm{K}-\mathrm{Ar}$ 法の原理亡問題点}

$\mathrm{K}-\mathrm{Ar}$ 法は, ${ }^{40} \mathrm{~K}$ が電子捕獲壊変して ${ }^{40} \mathrm{Ar}$ に変化する 物理現象を用いた年代测定法である（図 1 )。娘核種の ${ }^{40} \mathrm{Ar}$ が不活性な気体であるため, マグマが噴出・冷却 する時にマグマ中の ${ }^{40} \mathrm{Ar}$ は大気に放出され，大気了ル ゴンと同位体平衡に達するとほぼ仮定できるため（Dal- rymple，1969)，1 回の測定で 1 つの年代を求めること ができる。これは， $\mathrm{Rb}-\mathrm{Sr}$ 法などで試料以上の測定結 果からアイソクロン年代を求める方法とは異なり，モデ ル年代と呼ばれるものである。この簡便さが $\mathrm{K}-\mathrm{Ar}$ 法 の普及に役立っているが，大きな $2 つ$ 仮定の上に得ら れるということはあまり理解されていない。

1. 初生 ${ }^{40} \mathrm{Ar} /{ }^{36} \mathrm{Ar}$ 比が大気アルゴンの值 (= 295.5）に等しい

2. 放射時計がスタート（溶岩が噴出冷却）してか ら現在まで，試料の閉鎖系が保たれている（カリ ウム, アルゴンの出入りがない)

この仮定の妥当性について, 単なるアルゴンとカリウ ムの定量分析の結果である年代測定結果は，何の客観的 証拠 す提出しえない。したがって，火山岩の K-Ar 年 代が直ちに噴出年代をあらわす保証は全くなく，すべて の場合において，得られた年代值について何らかの主観 的あるいは客観的吟味が必要となる。ほとんどの場合 は, 年代值の地質学的解釉は, 解积する人の主観的判断 にゆだねられているのが現状である。しかし，これまで の多くの事例研究や室内実験の結果を参考にすれば, あ る程度客観的かつ論理的な判断に基づいて, 測定年代值 を合理的に解橎することが可能である。以下に，その合 理的判断基準示示。

仮定 1. の初生 ${ }^{40} \mathrm{Ar} /{ }^{36} \mathrm{Ar}$ 比の問題については，過剩

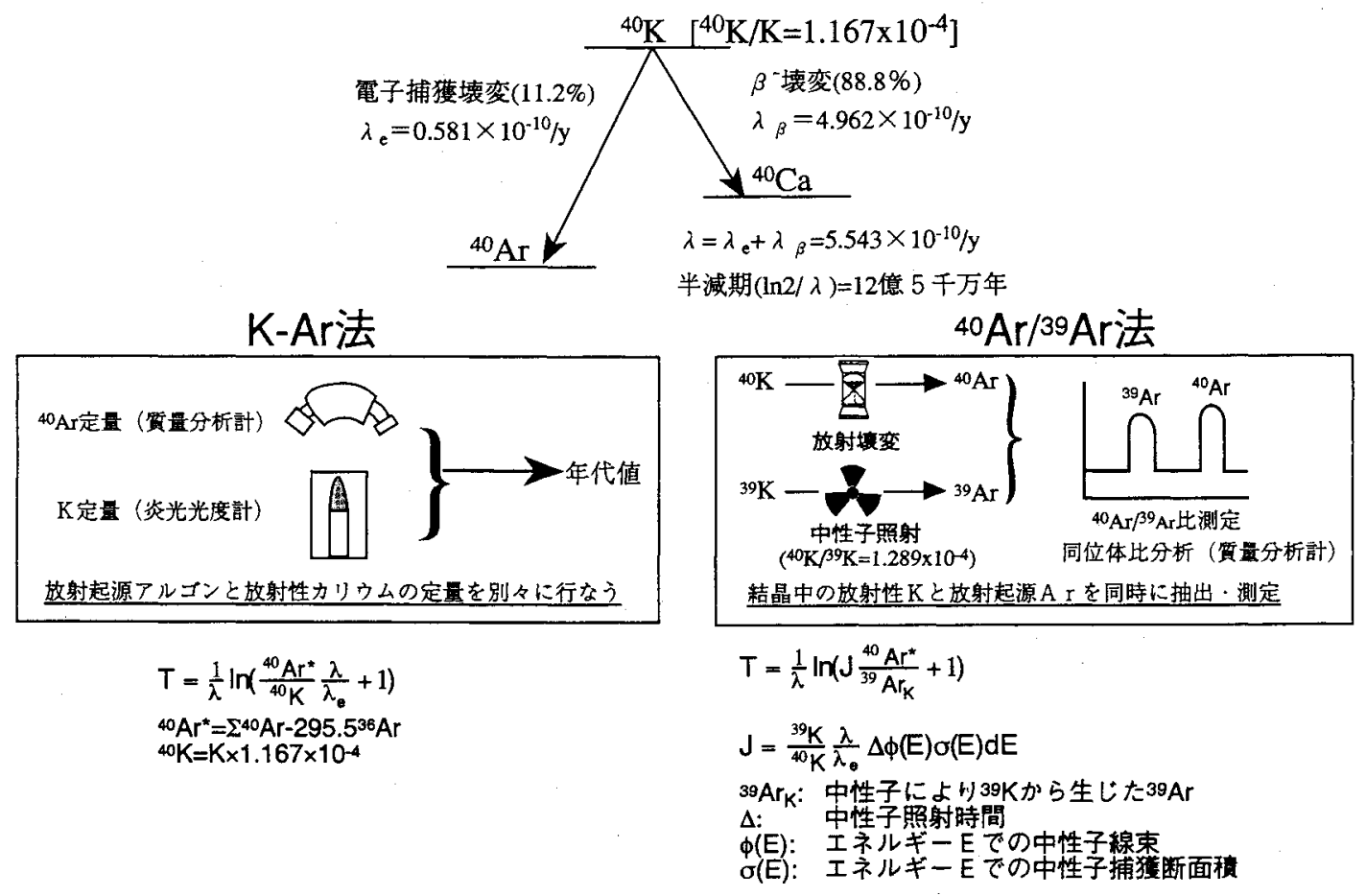

図 $1 \mathrm{~K}-\mathrm{Ar},{ }^{40} \mathrm{Ar} /{ }^{39} \mathrm{Ar}$ 年代測定法の原理 


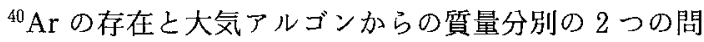
題がある。前者は, ${ }^{40} \mathrm{Ar} /{ }^{36} \mathrm{Ar}$ 比の高いマグマ中のアル ゴンが溶岩噴出時に大気中に逃げ切れず，溶岩中に取り 込まれたまま固結した場合に問題となる。水中噴出の溶 岩の急冷縁部に存在する (Dalrymple and Moore, 1968) ほか，マントルや深部地殼起源の異質結晶や大型斑晶に 含まれる。このため，急冷したガラス質岩石の測定は避 けたほうがよいし, 径数 $\mathrm{mm}$ を超す大型斑晶や異質岩 片, 結晶は取り除いたうえで年代測定することが望まし い。しかし，マントル起源のかんらん石や輝石の異質結 晶はさておき, 地款内マグマ溜り起源の斜長石, 輝石, 角閃石などの斑晶では，マグマ噴出時の ${ }^{40} \mathrm{Ar} /{ }^{36} \mathrm{Ar}$ 比は 高くても 350-370 程度であり (高岡, 1989 ; Hanyu and Kaneoka， 1997), 十分な量の放射起源 ${ }^{40} \mathrm{Ar}\left({ }^{40} \mathrm{Ar}^{*}\right)$ が 蓄積し, 高い ${ }^{40} \mathrm{Ar} /{ }^{36} \mathrm{Ar}$ 比を持っ第三紀火山岩類では大 きな影響は与えない。一方, 後者は, 溶岩の冷却固結時 に保持されるアルゴンが，大気アルゴンと同じ同位体比 を示さず，それから質量分別しているという問題で, ${ }^{40} \mathrm{Ar}^{*}$ の蓄積が少ない数十万年より若い火山岩において 重要な問題となる (Kaneoka, 1975; 高岡, 1989 ; 松本 ほ加1989)。しかし，斑晶鉱物の場合之同樣に高い ${ }^{40} \mathrm{Ar} /$ ${ }^{36} \mathrm{Ar}$ 比を持つ第三紀火山岩類で法, 初生 ${ }^{40} \mathrm{Ar} /{ }^{36} \mathrm{Ar}$ 比が 295.5 から多少ずれていても計算される年代值のずれは 大きくなく，あまり問題が生じない。以上から，仮定 1.の問題は，その影響を無視することはできないが, 第三紀火山岩類の年代測定においては比較的問題が少な いと結論づけられる。

一方，仮定 2 . の測定試料が噴出固結後に閉鎖系を 保っていたかどうかは，逆に古い岩石ほざ変質・変成作 用を被る機会が多いので，第三紀火山岩の年代測定に扔 いては大きな問題となる。したがって，多少なりとも風 化や变質作用の影響を被っている第三紀火山岩について $\mathrm{K}-\mathrm{Ar}$ 年代測定を行い, その結果を地質学的に解釈する 場合, 慎重な取り扱いが必要であり，何らかの主観的あ るいは客観的吟味が必要となる。第三紀以前の火山岩類 について K-Ar 年代測定し, その結果について意味づ けをする場合，以下のような点に留意する必要がある。

1. カリウムを含む鉱物・相が変質していない試料 を選ぶ

2. 石基が粗粒で完晶質な岩石を選ぶ

3. 石基ガラスに富む岩石は避ける

4. 灼熱隇量の大きい試料は避ける

5. 同時代で同程度の $\mathrm{K}_{2} \mathrm{O}$ 量を持つ他試料に比べ 大気混入率が著しく高い年代は要注意

6. 同層準あるいは連続層準の複数試料について年 代測定しクロスチェックする
7. 1 つの $\mathrm{K}-\mathrm{Ar}$ 年代のみに基づいて時代を議論し ない

まず当然ながら，カリウムを多く含む鉱物相が変質し ている岩石は， ${ }^{40} \mathrm{Ar}^{*}$ が散晩している可能性が大きい。 しかし，逆にカリウムを含まないかんらん石，輝石など の苦鉄質鉱物が粘土鉱物に変質していても $\mathrm{K}-\mathrm{Ar}$ 時計 への影響は無視できる。火山岩の場合, 黒雲母やカリ長 石の斑晶は例外として，カリウムは石基に濃集してい る。したがって; 石基の結晶度, 粒径, 鉱物組み合わせ は，測定試料を選定するうえで重要な観察事項となる。 石基が粗粒で完晶質な岩石では，カリウムは長石，角閃 石, 雲母に存在するので, ${ }^{40} \mathrm{Ar}^{*}$ はしっかり結晶内に保 持され散逸する可能性は低い。一方，石基ガラスは不安 定な相であり，容易に風化变質あるいは加水作用を受け やすい。アルゴンと水の分子の大きさはほぼ同じである ので，ガラスに水が入りやすいということは，逆に ${ }^{40} \mathrm{Ar}$ *が系外に逃げやすいことを意味する (Dalrymple and Lanphere, 1969 ; Kaneoka, 1972)。Mankinen and Dalrymple (1972) は，石基が完晶質な試料とガラスに 富む試料について，EPMA を用いて岩石中でのカリウ ム分布を示しながら. $\mathrm{K}-\mathrm{Ar}$ 年代の信頼性を議論し，ガ ラス質な石基を持つ岩石はたと元見か上新鮮でも ${ }^{40} \mathrm{Ar}^{*}$ を失っており，地質学的に意味のある年代が得ら れなかったことを明らかにした。また，Kaneoka （1972）は，黒羅岩の含水量と $\mathrm{K}-\mathrm{Ar}$ 年代の相関を議論 し，加水するほど ${ }^{40} \mathrm{Ar} *$ の散逸が大きいことを示した。 したがって，ガラスに富む試料の $\mathrm{K}-\mathrm{Ar}$ 年代測定は, 極力避けるかあるいは測定に当たって十分な記載岩石学 的検討が必要である。この問題については，1事例を後 述する。ガラスの水和や粘土鉱物の生成により, 風化変 質した岩石は $\mathrm{H}_{2} \mathrm{O}$ に富屯。したがって，灼熱減量の多 少は， $\mathrm{K}-\mathrm{Ar}$ 年代測定試料判別の一種の客観的指標であ り, 灼熱減量が $1-2 \%$ 超える岩石は年代測定に適し ない (Kaneoka, 1972)。また，変質作用により形成され た粘土鉱物には大量の大気アルゴンが吸着している。新 鮮な岩石における大気アルゴンの混入量は, $5 \times 10^{-7} \mathrm{~m} l$ $\mathrm{STP} / \mathrm{g}$ 程度以下である (Dalrymple and Lanphere, 1969）ので， ${ }^{40} \mathrm{Ar} *$ が $1 \times 10^{-7} \mathrm{~m} / \mathrm{STP} / \mathrm{g}$ を超える第三紀 火山岩では大気混入率は $80 \%$ 以下であるはずである。あ し, 得られた $\mathrm{K}-\mathrm{Ar}$ 年代の大気混入率がそれより高い 場合，测定試料に問題があることになり，要注意であ る。最後に, 当然のことながら, 年代未知試料の形成年 代をただ 1 つの K-Arr 年代で判断するのは危険であり, 常に他の年代情報とクロスチェックすることは重要であ る。できれば，同一あるいは連続層準の複数試料につい て年代測定を行い，年代結果が矛盾しないことを確認す 
ることが望ましい。

\section{3. ${ }^{40} \mathrm{Ar} /{ }^{39} \mathrm{Ar}$ 法の原理とメリット}

${ }^{40} \mathrm{Ar} /{ }^{39} \mathrm{Ar}$ 法は, $\mathrm{K}-\mathrm{Ar}$ 法と同じ物理時計，すなわち ${ }^{40} \mathrm{~K}$ の電子捕獲壊変による ${ }^{40} \mathrm{Ar}$ の生成という現象を用い ながら，多くのメリットを有している。大きな違いは， 原子炉において测定試料に速中性子を照射し， ${ }^{39} \mathrm{~K}$ を ${ }^{39} \mathrm{Ar}$ に変換することである(図 1 )。天然の岩石中の ${ }^{40} \mathrm{~K}$ $/{ }^{39} \mathrm{~K}$ 比は一定であるので, 原子炬における ${ }^{39} \mathrm{~K}$ からの ${ }^{39} \mathrm{Ar}$ の生成率が分かれば, 中性子照射後の試料中の ${ }^{40} \mathrm{Ar} /{ }^{39} \mathrm{Ar}$ 比を測定することで試料の年代を知ることが できる。 ${ }^{40} \mathrm{Ar} /{ }^{39} \mathrm{Ar}$ 法の詳しい原理, 利点については, 兼岡 (1988 a), 宇都 (1993), 宇都・石生 (1996) に詳 しいので,ここでは省略するが，第三紀火山岩の正確で 精密な年代測定に最む有効なのは段階加熱法である。そ れにより，得られる年代值をかなりの程度客観的に評洒 することが可能である。段階加熱法とは，測定試料を低 温から高温にかけてある一定時間ずつ段階的に加熱し， 各温度ごとに試料から放出されるアルゴンの同位体比測 定を行い，おのおのの温度フラクションの年代を求める 湘定法である。その結果を用いて行う客観的判断手法と して，年代スペクトル図を用いたプラト一年代の認定 (図 2）と，アイソクロン図によるアイソクロン年代の 計算の 2 種類がある。この 2 つの罒を用いることで $\mathrm{K}-$ $\mathrm{Ar}$ 年代に拈ける 2 つ仮定が成り立っているかどうか の判断ができるばかりか，成り立たない場合には，真の 初生 ${ }^{40} \mathrm{Ar} /{ }^{36} \mathrm{Ar}$ 比の推定あるいは閉鎖系の保たれている 部分のみの抽出を行うことが可能である。例えば，変質 作用や再加熱により容易にアルゴンを放出しやすい不安 定な鉱物相は，段階加熱により比較的低温でアルゴンを 放出するが，高温まで安定な鉱物相は段階加熱でも主に 高蕰部でアルゴンを放出する。したがって，変質作用に
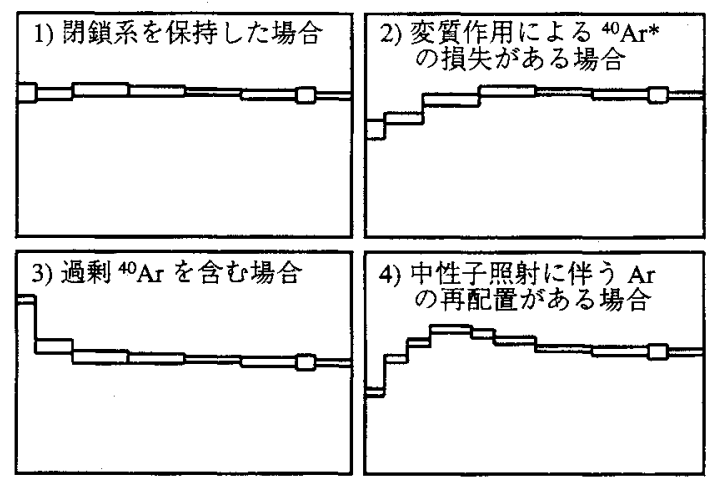

図 2 火山岩全岩試料によく見られる模式的な段 階加熱年代スペクトラ
より ${ }^{40} \mathrm{Ar}$ が多少散逸している岩石を年代測定した場合， 低温部分では乱れた年代スペクトラを示すが，中温一高 温部分では安定した年代スペクトラが得られる。年代プ ラトーの認定は, 高温部分の連続した 3 スップ以上の 加熱年代值が95\%信頼限界の範目で一致し， かつ全体の ${ }^{39} \mathrm{Ar}$ の0\%以上を含むことであり，プラトーを構成す る年代值すべての加重平均值をプラトー年代とする (Dalrymple et al., 1980 な゙)。一方, アイソクロン図 では, プラトーを構成する温度フラクションの測定デー 夕を通常のアイソクロン図 $\left({ }^{40} \mathrm{Ar} /{ }^{36} \mathrm{Ar}-{ }^{39} \mathrm{Ar} /{ }^{36} \mathrm{Ar}\right)$ ある いは逆アイソクロン図 ( $\left.{ }^{36} \mathrm{Ar} /{ }^{40} \mathrm{Ar}-{ }^{39} \mathrm{Ar} /{ }^{40} \mathrm{Ar}\right)$ にプロッ トし,アイソクロンを計算するものであり, 初生 ${ }^{40} \mathrm{Ar}$ / ${ }^{36} \mathrm{Ar}$ 比を 295.5 と仮定することなく計算で求めることが できる。そのため, 過剩 ${ }^{40} \mathrm{Ar}$ の存在の有無をチェック することが可能である。しかし， ${ }^{40} \mathrm{Ar} /{ }^{39} \mathrm{Ar}$ 段階加熱法 によるアイソクロンでは，鉱物からの拡散による脱ガス プロセスを再現しているので, 実験上の見せかけのアイ ソクロンが得られることがある (Lanphere and Dalrymple, 1978)。したがって, 初生 ${ }^{40} \mathrm{Ar} /{ }^{36} \mathrm{Ar}$ 比が295.5か ら著しく外れるものは，注意して吟味する必要がある。 以上の点加，信頼性の高い ${ }^{40} \mathrm{Ar} /{ }^{39} \mathrm{Ar}$ 段階加熱年代と は以下のように定義されている (Lanphere and Dalrymple, 1978 ; Dalrymple et al., 1980)：1. 前述どおりの プラトー年代が得られること，2．プラトー部分のデー タでアイソクロンが引けること，3．プラトー，アイソ クロン両年代が95\%信頼限界の範囲で一致すること，4. アインクロンの初生 ${ }^{40} \mathrm{Ar} /{ }^{36} \mathrm{Ar}$ 比が295.5と著しく異な らないこと。

\section{4. 第三紀火山岩への ${ }^{40} \mathrm{Ar} /{ }^{39} \mathrm{Ar}$ 年代測定の応用}

近年, 連続レーザを用いて数 $m g$ 以下の極めて少量 の岩石・鉱物試料を加熱融解するレーザ加熱 ${ }^{40} \mathrm{Ar} /{ }^{39} \mathrm{Ar}$ 年代測定技術が開発され，なるべく変質していない数 $\mathrm{mm}$ 角以下の岩石・鉱物試料を選び出し，迅速に年代 測定できるようになった（宇都・石塚，1996；Uto et al., 1997)。これにより，変質作用の影響を免れえな かった第三紀火山岩類の正確で精密な年代が得られるよ うになりつつある。以下に，火山岩石基の段階加熱年代 測定の具体例を 2 例と，斑晶銃物 1 一数粒子を用いた全 融解年代測定 1 例を紹介し，レーザ加熱 ${ }^{40} \mathrm{Ar} /{ }^{39} \mathrm{Ar}$ 年代 測定の有用性を述べ，将来を展望する。以下の具体例 は，著者と共同研究者たちにより現在進行中の研究の一 部であり，今後の測定などにより年代や地質解釈が多少 変更される可能性があることをあらかじめ断っておく。

\section{1 高渋山層火山岩}

図 3 は，島根半島の先端部に分布する中期中新統高渋 
山層中の玄武岩質安山岩溶岩 (K-Ar 年代 : $9.7 \pm 1.6$ Ma) の段階加熱年代測定結果である (Uto et al., 1997)。 全体を13のステップに切って, レーザの出力を徐々に上 げて段階加熱を行い, 各ステップごとに得られる年代を 土68\%信頼限界の幅で示したものである。最初の 1 ス テップを除き，残りの12ステップの年代はすべて95\%信 頼限界の範囲で一致しており, その加重平均として $12.29 \pm 0.15 \mathrm{Ma}$ のプラトー年代が得られる。また，ア イソクロン, 逆アイソクロン年代は, 共に $12.5 \pm 0.5$ $\mathrm{Ma}$ で，プラト一年代に一致する。この試料は完晶質で 石基にわずかに粘土鎕物が生じているだけであり， $\mathrm{K}-$ $\mathrm{Ar}$ 年代測定に適した試料である。そのため, 年代スぺ クトラもごく低温部以外は乱されていない。したがっ て, 既存の K-Ar 年代とプラトー年代は誤差 $(2 \sigma)$ の範 囲で一致するが, 後者のほうが䛊差が10分の 1 以下と精 度の高い年代值である。高渋山層の対比については，松 江市周辺に分布する松江層 (11-12 Ma) に対比する説 （鹿野·吉田, 1985）と, 牛切層 (14-15 Ma) に対比す る説 (Morris et al., 1990) が存在したが, 本年代測定の 結果, 年代的には松江層に対比されることが確認され た。

\section{2 高山斑れい岩およひ山島火山岩}

山口県北東部須佐地域の高山岬および周辺部には, 中 期中新統の須佐層群を貫く苦鉄質貫入岩体，高山斑れい 岩とその噴出岩相と推定される山島火山岩が分布する

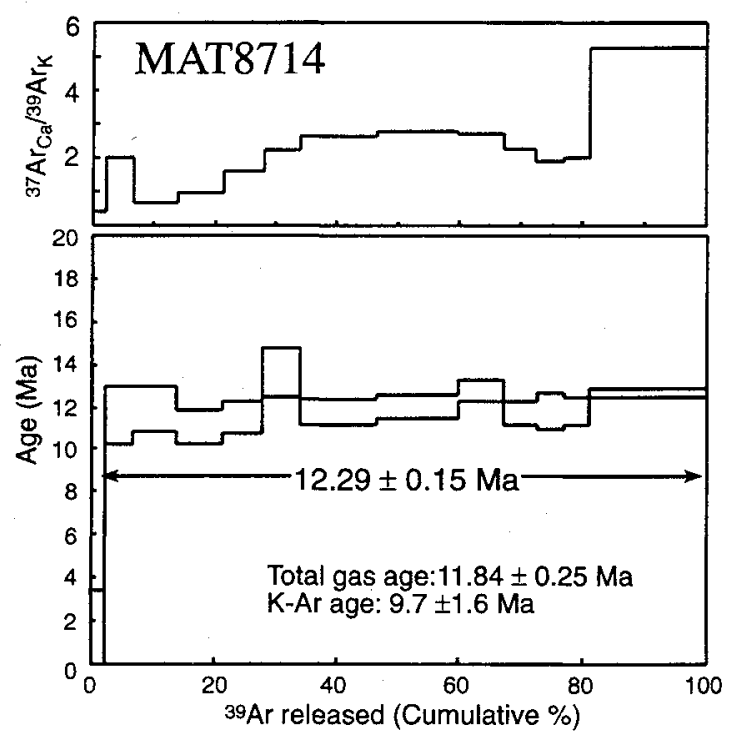

(今岡ほか, 1997)。高山斑れい岩については,これまで $14.0 \pm 0.7 \mathrm{Ma}$ (Matsumoto and Itaya, 1986), 14.5士

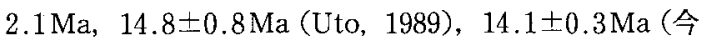
岡ほか，1997）の比較的よく一致した年代が得られてい る。一方, 同斑れい岩の噴出岩相と推定される山島火山

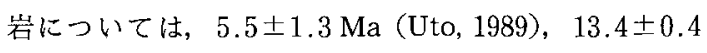
$\mathrm{Ma}, 14.2 \pm 0.5 \mathrm{Ma}$ (今岡ほ加, 1997), 同火山岩を貫く 岩脈は $12.1 \pm 0.6 \mathrm{Ma}$ (今岡ほか，1997）と斑れい岩之一 致するものから著しく若いものまで幅広い範囲の年代が 得られている。今岡ほか（1997）は, 測定した火山岩試 料にはわずかの緑泥石が形成されているのみで， ${ }^{40} \mathrm{Ar} *$ の散逸はなく，火山活動が約 $13 \mathrm{Ma}$ まで継続したと主 張している。一方, Uto (1989) が測定した試料は新鮮 であり，顕微鏡下では変質鉱物は認められない。しか し，斑れい岩の 2 試料が粗粒完晶質であるのに対し，愦 差を超えて若い年代を示す噴出岩（G31）は石基の褐色 ガラスが多い。前述した Mankinen and Dalrymple （1972）に従えば，G31 はガラスからの ${ }^{40} \mathrm{Ar}$ *の散逸に より噴出年代より若い年代を与えている可能性が高い。 このことを確かめるために，G31 と斑れい岩の周縁部か ら採取した斑状で粗粒完晶質な G64の2 試料について ${ }^{40} \mathrm{Ar} /{ }^{39} \mathrm{Ar}$ 段階加熱年代測定を行った（図 4)。粗粒完晶 質な G64 は, 全 9 ステップ中最初の 1 ステップを除き 残り 8 ステップにおいて一致する年代が得られ，これら の加重平均として $14.41 \pm 0.11 \mathrm{Ma}$ のプラトー年代が計
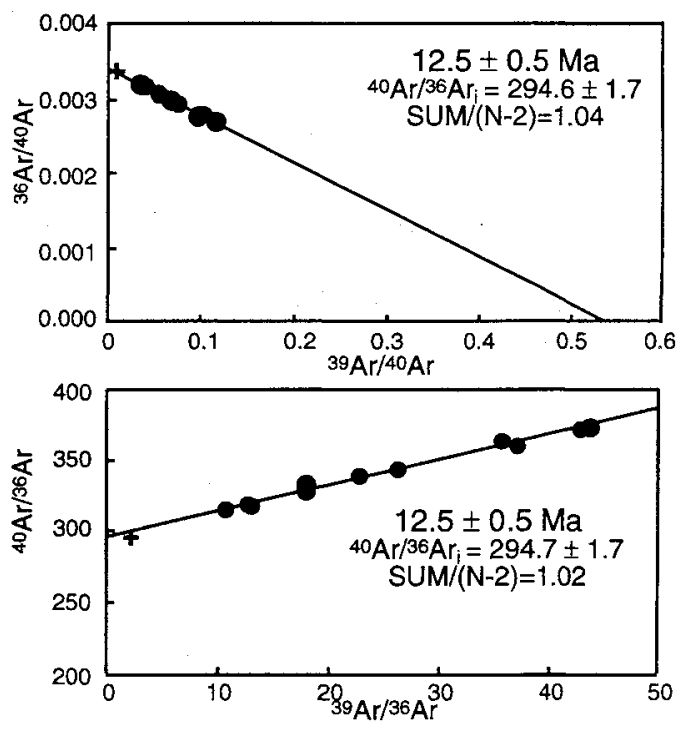

図 3 島根半島高啮山層安山岩溶岩の段階加熱 ${ }^{40} \mathrm{Ar} /{ }^{39} \mathrm{Ar}$ 年代スペクトラおよびアイソクロン (Uto et al., 1997)。 アイソクロン図中の+は，プラトーを構成しないデータで，アイソクロン計算からは除外。 プラトーを構成する部分（○）のみを用いて年代を計算。 
算される。アイソクロン図中の波線および斜め文字の数 字は，プラトーを構成するすべての段階実験結果を用い て計算した結果であり, 最む信頼性の高い高 ${ }^{39} \mathrm{Ar} /{ }^{36} \mathrm{Ar}$ 比のフラクションでのフィッティングが悪い。また, フィッティングのよさを示す $\mathrm{SUM} /(\mathrm{N}-2)$ 值も19と極 めて悪く、この回帰計算に意味がないことを示してい る。一方，実線で示したあのは，低温部分（黒三角）を
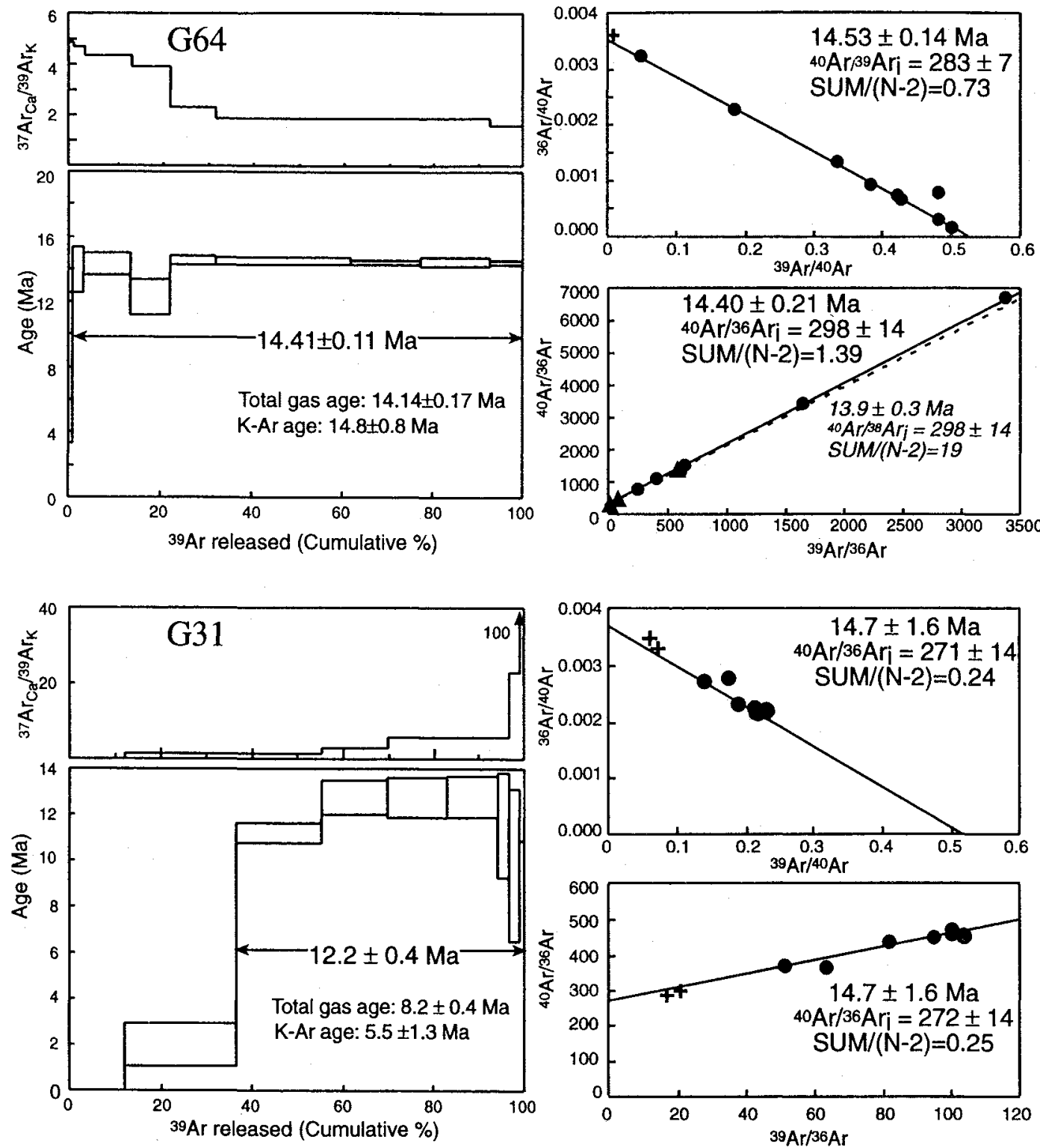

図 4 山口県須佐地域高山斑饥い岩（G64）之山島火山岩（G31）の段階加熱 ${ }^{40} \mathrm{Ar} /{ }^{39} \mathrm{Ar}$ 年代測定結 果。

G64のアインクロンの波線扔よび斜め文字は，プラト一部分全部を含めて計算した結果。実 線で示したものは，低温部分（山）をはずして計算したもの。十，のは，図 4 に同じ。 
分析誤差は 7 分の 1 上著しく小さくなった。一方，石基 ガラスに富むG31 においては，低温の2ステップでは ${ }^{39} \mathrm{~K}$ 起源の ${ }^{39} \mathrm{Ar}\left({ }^{39} \mathrm{Ar}_{\mathrm{K}}\right)$ が全体の約 $35 \%$ が脱ガスしたに むかかわらず， ${ }^{40} \mathrm{Ar}$ ははとんど放出されず，計算され る年代は $3 \mathrm{Ma}$ 以下である。しかし，高温側の 7 ステッ プでは，急激に ${ }^{40} \mathrm{Ar}^{*}$ が脱ガスされ，全体の ${ }^{39} \mathrm{Ar}_{\mathrm{K}}$ の約 $65 \%$ で定義上の $12.2 \pm 0.4 \mathrm{Ma}$ のプラトー年代が得られ た。全ステップのアルゴンの合計で計算される全ガス年 代は $8.2 \pm 0.4 \mathrm{Ma}$ と著しく若く, $\mathrm{K}-\mathrm{Ar}$ 年代 $5.5 \pm 1.3$ Ma に測定上の問題があったわけではないことを示す。 ${ }^{40} \mathrm{Ca}$ 起源の ${ }^{37} \mathrm{Ar}\left({ }^{37} \mathrm{Ar}_{\mathrm{Ca}}\right)$ 之 ${ }^{39} \mathrm{Ar} \mathrm{r}_{\mathrm{K}}$ の比の脱ガスパターン を見ると，温度が上がるにつれ次第に $\mathrm{Ca} / \mathrm{K}$ が上がり， $\mathrm{Ca} / \mathrm{K}$ 比の低い褐色ガラスから $\mathrm{Ca} / \mathrm{K}$ 比の高い斜長石へ 之, ${ }^{40} \mathrm{Ar}^{*}$ と ${ }^{39} \mathrm{Ar}_{\mathrm{K}}$ の主たる放出源が变化したことが示 される。これらから，全体のカリウムの約 $40 \%$ 以上を保 持している火山ガラスが ${ }^{40} \mathrm{Ar}$ 在保持しえなかったた め，噴出年代上り若い $\mathrm{K}-\mathrm{Ar}$ 年代が得ら机たこ之が示 唆される。前述の定義どおりの，すなわち連続 7 ステッ プが埕差の範囲で一致し，全 ${ }^{39} \mathrm{Ar}_{\mathrm{K}}$ の65\%を占めるプラ ト一年代が得られているが，この年代は $\mathrm{G} 64$ や前述の 既存 $\mathrm{K}-\mathrm{Ar}$ 年代より明らかに若い。プラト一年代をよ く見ると，2 ステップめの $2.1 \pm 0.9 \mathrm{Ma}$ から 3 ステップ めの $11.1 \pm 0.7 \mathrm{Ma}$ と急に年代が変化するが, 3 ステッ プめは低温の ${ }^{40} \mathrm{Ar}$ *が散逸した部分と高温の保持部分の 湿合である可能性がある。すし，3 ステップめをはずし て残りの高温 6 ステップでの加重平均を取ると, ${ }^{39} \mathrm{Ar}_{\mathrm{K}}$ が45\%で $12.7 \pm 0.5 \mathrm{Ma}$ と若干古めの年代がえら れるが，それであ依然として若い年代であることに変わ りない。アイソクロン, 逆アイソクロン年代は, いずれ む $14.7 \pm 1.6 \mathrm{Ma}$ で斑れい岩と一致する年代を与える が, 初生 ${ }^{40} \mathrm{Ar} /{ }^{36} \mathrm{Ar}$ 比が $271 \pm 14,272 \pm 14$ と大気アルゴ ンょり低い值を示し，信頼性に多少の問題が残る。本実 験は，原子炬での中性子照射加ら約 1 年後に測定したも ので, 妨害核種である ${ }^{40} \mathrm{Ca}$ 起源の ${ }^{36} \mathrm{Ar}\left({ }^{36} \mathrm{Ar}_{\mathrm{Ca}}\right)$ と ${ }^{42} \mathrm{Ca}$ 起源の ${ }^{39} \mathrm{Ar}\left({ }^{39} \mathrm{Ar}_{\mathrm{Ca}}\right)$ を補正する ${ }^{37} \mathrm{Ar}_{\mathrm{Ca}}$ (半減期 35.1 日) が減衰しすぎており，測定值の誤差が大きいばかりか， 補正上で多少の問題がある可能性が高い。本試料は再測 定を準備中でありここでは上記のプラトー,アイソク ロン年代の地質学的意義については議論をしない。いず れにせ上, 山島火山岩の ${ }^{40} \mathrm{Ar} /{ }^{39} \mathrm{Ar}$ 段階加熱年代測定加 ら，たとえ見かけ上新鮮であ石基ガラスに富む火山岩の $\mathrm{K}-\mathrm{Ar}$ 年代測定は避けるべきであり，なるべく結晶質な 岩石を選ぶことが重要であることが明らかとなった。

\section{3 歌長流紋岩}

レーザ加熱 ${ }^{40} \mathrm{Ar} /{ }^{39} \mathrm{Ar}$ 年代測定法のもう一つのメリッ 卜は, 結晶を 1一数粒子ずつ迅速に年代测定できる点で
ある。K-Ar 法の場合, 試料をカリウムの定量とアルゴ ンの定量に二分割しなければならないので，原理的に結 晶 1 粒子ごとの年代測定はできないが， ${ }^{40} \mathrm{Ar} /{ }^{39} \mathrm{Ar}$ 法で は可能である。第三紀火山岩では, 石基が变質作用を 被っていても斑晶鉱物，特に斜長石は未变質のまま残っ ていることが多い。また，K-Ar 法では全岩年代測定が できないガラスに富む火砕物中にも, 斜長石, 黒雲母, 角閃石などの新鮮な斑晶鉱物が含まれている。これらの 斑晶鈸物 1 粒子ごとの年代湘定を可能にすることで，こ れまで $\mathrm{K}-\mathrm{Ar}$ 年代測定できなかった多くの火山物質の年 代を決定することができると期待される。その一例とし て山陰地方東部の鮮新世後期の歌長流紋岩から分離した 黒雲母の年代測定結果を示す（図 5 )。本溶岩について は，すでに $2.48 \pm 0.02 \mathrm{Ma}$ (黒雲母 $\mathrm{K}-\mathrm{Ar}$ 年代)，1.94 $\pm 0.14 \mathrm{Ma}$ (サニディン $\mathrm{K}-\mathrm{Ar}$ 年代), $2.72 \pm 0.11 \mathrm{Ma}$ (ジルコンフィッショントラック年代) が得られている (宇都ほか，1994）。黒雲母 8 測定のうち誤差の小さい 6 测定は，2.5 Ma 前後に集中し，他の 2 測定も誤差の範 囲で一致する（図 5 )。㕵差を考虑した相対頻度分有は, 8 測定の加重平均値 $2.52 \pm 0.02 \mathrm{Ma}$ をピークとした両対 称なパターンを示し，すべての測定がいずれあ問題がな いこと，誤差の見積もりが妥当なことを示唆する。加重 平均值 $2.52 \pm 0.02 \mathrm{Ma}$ は, この試料の $\mathrm{K}-\mathrm{Ar}$ 年代 (2.48 $\pm 0.02 \mathrm{Ma}$ ）上誤差範囲で一致する。以上加ら, 結晶 1 粒子ごとの ${ }^{40} \mathrm{Ar} /{ }^{39} \mathrm{Ar}$ 年代測定の信頼性が高いことが示 される。カリ長石, 斜長石斑晶についてそれぞれ 3 測定 ずつ予備的な ${ }^{40} \mathrm{Ar} /{ }^{39} \mathrm{Ar}$ 年代を行ったところ，2.44士 $0.05 \mathrm{Ma}$ および $2.47 \pm 0.14 \mathrm{Ma}$ と，いずれも黒雲母年代 とよく一致する加重平均年代が得られている。カリ長石 は著しくカリウムに富む鉱物であるが，高融点であるた

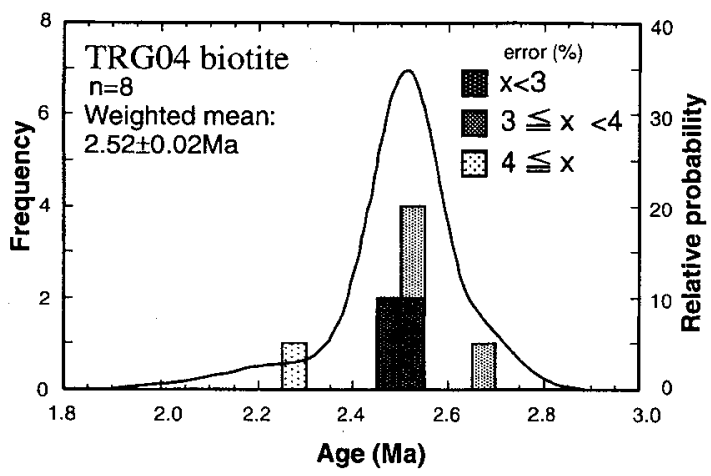

図 5 山陰地方照来層群歌長流紋岩の黒雲母斑晶 1 粒子ごとの全融解 ${ }^{40} \mathrm{Ar} /{ }^{39} \mathrm{Ar}$ 年代測定結 果。

太線は，測定誤差を考慮に入れた相対確率 密度曲線を示す（Uto et al., 1997)。 
$め^{40} \mathrm{Ar}^{*}$ を完全に抽出することが困難で，しばしば若い $\mathrm{K}-\mathrm{Ar}$ 年代を示すことが指摘されており（宇都ほか, 1994)，本試料で㫗 $\mathrm{K}-\mathrm{Ar}$ 年代は $1.94 \pm 0.14 \mathrm{Ma}$ と黒雲 母に比べて有意に若かった。しかし， ${ }^{40} \mathrm{Ar} /{ }^{39} \mathrm{Ar}$ 測定を 用いれば，信頼性の高い年代が得られることが明らかで あり，斜長石ととあに今後の応用が期待できる。

\section{5.おわりに}

本総説においては，風化変質作用を少なからず被って いる第三紀火山岩類の K-Ar 年代測定を行う際, 湘定 試料の十分な記載岩石学的検討が重要であることを示し た。特に，石基がラス質に富む岩石は放射起源 ${ }^{40} \mathrm{Ar}$ を 散逸させている可能性が高いので，年代测定を避ける必 要があることを，山島火山岩の例を上げて示した。 $\mathrm{K}$ $\mathrm{Ar}$ 年代值は, カリウムとアルゴンの化学分析值を元に, いくつかの仮定をおいて算術的に計算される数值である ので，その地質学的解积にあたっては，1つの年代值の みを無批判に用いることはせず，できれば同一あるいは 連続層準の複数武料の年代の整合性を吟味することが重 要である。その点で, 分析結果の客観的な検討が可能で ある ${ }^{40} \mathrm{Ar} /{ }^{39} \mathrm{Ar}$ 段階加熱年代测定法は，第三紀火山岩類 の正確で精密な年代測定においては，大变に有用である ことを，最近のレーザ加熱年代測定結果を用いて紹介し た。また，黑雲母斑晶の 1 一数粒子年代测定の有用性屯 示した。

現在, 筆者たちは, 日本海の拡大前後に噴出した火山 岩類の系統的なレーザ加熱 ${ }^{40} \mathrm{Ar} /{ }^{39} \mathrm{Ar}$ 段階加熱年代測定 を実施中である。それによれば，西南日本の時計回り回 転後に噴出したとされる山陰地方大森層火山岩類の噴出 年代が， $\mathrm{K}-\mathrm{Ar}$ 年代测定に基づく $14 \mathrm{Ma}$ 前後 (Otofuji et al., 1991) ではなく，15-16 Ma であることが明らかに なりつつある。すると, 西南日本の回転連動は, これま で考えられてきたより 200 万年以上前に終了したことに なる。また，ODP で掘削された大和海盆の火山岩の噴 出, 貫入年代について手測定中であり, Kaneoka et al. （1991）の結果と調和的な 17.5-18.5 Ma 前後の年代がえ られつつある。これらのことから日本海の拡大は，16 Maころにはほぼ終了していた可能性が強くなりつつあ る。今後, ${ }^{40} \mathrm{Ar} /{ }^{39} \mathrm{Ar}$ 年代湘定に基づくより正確な時代 論を元に，日本列島の構造発達史を明らかにできると期 待している。

\section{謝 辞}

石油技術協会シンポジウムでの講演および本論文執筆 の機会を与えてくださったシンポジウム企画委員会の各 位，特に石油資源開発株式会社の秋葉文雄氏に深謝す る。三井石油開発株式会社探鉱部の䈎岡 健氏には丁寧
な查読をしていただいた。高山斑れい岩および山島火山 岩の年代学は，干葉大学理学部地球科学科の津久井雅史 助教授との共同研究であり，本論文での一部公表を認め ていただいた。また，大森層火山岩については地躓調查 所地質部鹿野和彦氏，大和海盆火山岩については東京大 学地震研究所兼岡一郎教授とそれぞれ共同研究中であ る。 $\mathrm{K}-\mathrm{Ar}$ 実験において, 地質調查所地款化学部内海 茂氏と同大阪地域地質センター青山秀喜氏にご援助いた だいている。記してお礼申し上げる。

\section{引用 文 献}

Dalrymple, G.B., $1969:{ }^{40} \mathrm{Ar} /{ }^{36} \mathrm{Ar}$ analyses of historic lava flows. Earth Planet. Sci. Lett., 6, 47-55.

Dalry mple, G.B. and Lanphere, L.A., 1969 : PotassiumArgon Dating. Freeman and Co., San Francisco, 258 pp.

Dalrymple, G. B., Lanphere, L. A. and Clague, D. A., 1980 : Conventional and ${ }^{40} \mathrm{Ar} /{ }^{39} \mathrm{Ar} \mathrm{K}$-Ar ages of volcanic rocks from Ojin (Site 430), Nintoku (Site 433) seamounts and the chronology of volcanic propagation along the Hawaiian-Emperor chain. Initial Rep. Deep Sea Drill. Proj., 55, 54-76.

Dalrymple, G. B. and Moore, J.G., 1968 : Ar gon-40 : Excess in submarine pillow basalts from Kilauea Volcano, Hawaii. Science, 161, 1132-1135.

Hanyu, T. and Kaneoka, I., 1997 : Magmatic processes revealed by noble gas signatures: the case of Unzen Volcano, Japan. Geochem. J., 31, 395-405.

今岡照喜 - 西村裕二郎 · 後藤芳彦 - 中島和夫 · 斎藤和 男・板谷徹丸, 1997 ：山陰西部山島火山岩の産状と K$\mathrm{Ar}$ 年代．岩鉱, 92, 302-315.

板谷徹丸・長尾敬介, 1988：100万年より若い火山岩の K -Ar 年代测定．地質学論集, No. 29, 143-161.

Kaneoka, I., 1972 : The effect of hydration on the K/ Ar ages of volcanic rocks. Earth Planet. Sci. Lett., 14, 216-220.

Kaneoka, I., 1975 : Non-radiogenic argon in terrestrial rocks. Geochem. I., 9, 113-124.

兼岡一郎, $1988 \mathrm{a}:{ }^{40} \mathrm{Ar}-39 \mathrm{Ar}$ 法による年代測定一基礎之 その問題点一。地質学論集, No. 29, 23-36.

兼岡一郎, $1988 \mathrm{~b}:{ }^{40} \mathrm{Ar}-{ }^{39} \mathrm{Ar}$ 法による火山岩類の年代測 定一地球科学への応用一。地質学論集, No.29, 163175 .

Kaneoka, I., Takigami, Y., Takaoka, N., Yamashita, S. and Tamaki, K., $1992:{ }^{40} \mathrm{Ar}-{ }^{39} \mathrm{Ar}$ analysis of volcanic rocks recovered from the Japan Sea floor : Constraints on the age of formation of the Japan Sea. Proc.Ocean Drilling Rept., Sci. Results, 127/128, 819 836.

鹿野和彦・吉田史郎，1985：境港地域の地質。地域地質 研究報告 ( 5 万分の 1 地質四幅), 地質調査所, $57 \mathrm{p}$.

Lanphere, M. A. and Dalrymple, G. B., 1978: The use 
of ${ }^{40} \mathrm{Ar} /{ }^{39} \mathrm{Ar}$ data in evaluation of disturbed $\mathrm{K}-\mathrm{Ar}$ systems. U. S. Geol. Surv. Open-File Rept., 78-701, 241-243.

Mankinen, E. A. and Dalrymple, G. B., 1972 : Electron microprobe evaluation of terrestrial basalts for whole-rock K-Ar dating. Earth Planet. Sci. Lett., 17, 89-94.

Matsumoto, H. and Itaya, T., 1986 : Chronological study of contact metamorphic rocks in SusaKoyama area, Yamaguchi Prefecture. Bull. Hiruzen Res. Inst., Okayama Univ. Sci., 12, 9-17.

松本哲一・宇都浩三・柴田 賢, 1989 : 歴史溶岩のアル ゴン同位体比一若い火山岩の $\mathrm{K}-\mathrm{Ar}$ 年代測定におけ る初生值補正の重要性一. 質量分析, 37, 353-363.

McDougall, I. and Harrison, T. M., 1988 : Geochronology and Thermochronology by the ${ }^{40} \mathrm{Ar} /{ }^{39} \mathrm{Ar}$ method. Oxford Univ. Press, Oxford, New York, 212 pp.

Morris, P. A., Itaya, 'T., Watanabe, T. and Yamauchi, S., 1990 : Pottasium/argon ages of Cenozoic igneous rocks from eastern Shimane Prefecture-Oki Dozen Island, southwest Japan and the Japan Sea opening. J. Southeast Asian Earth Sci., 4, 125-131.

Otofuji, Y., Itaya, T. and Matsuda, T., 1991 : Rapid rotation of southwest Japan-paleomagnetism and $\mathrm{K}$-Ar ages of Miocene volcanic rocks of southwest
Japan. Geophys. J. Intl., 105, 397-405.

柴田 賢, 1985 : 地質年代学に関する技術的進歩と日本 に打的代学的研究. 地質学論集, No. 25, 391-405. 高岡宣雄, 1989 : 百万年より若い火山岩の K-Ar 年代测 定における問題点. 質量分析, 37 (6), 343-351.

Uto, K., 1989 : Neogene volcanism of Southwest Japan : its time and space based on $K$-Ardating. Ph.D. Thesis, 184 pp., Univ. Tokyo.

宇都浩三, 1993 : 極微量 ${ }^{40} \mathrm{Ar}-{ }^{39} \mathrm{Ar}$ 年代測定にむけて一 斜長石一粒の精密年代測定法を目指す一, 地質二ュー ㅈ, No. 461, 32-39.

宇都浩三, 1996 : 火山と年代测定 : K- $\mathrm{Ar},{ }^{40} \mathrm{Ar} /{ }^{39} \mathrm{Ar}$ 年代 測定の現状亡将来. 火山, 40, S27-S46.

宇都浩三・石塚 治, 1996 ：レーザ融解法による極微量 ${ }^{40} \mathrm{Ar} /{ }^{39} \mathrm{Ar}$ 年代測定法の開発. 地質二ュース，No. 504， $7-18$.

Uto, K., Ishizuka, O., Matsumoto, A., Kamioka, H. and Togashi, S., 1997 : Laser-fusion ${ }^{40} \mathrm{Ar} /{ }^{39} \mathrm{Ar}$ dating system of the Geological Survey of Japan : System outline and preliminary results. Bull. Geol. Surv. Japan, 46 (1), 23-46.

宇都浩三・田上高広・内海 茂, 1994 ：山陰地方東部, 鮮 新統照来層群火山岩類の $\mathrm{K}-\mathrm{Ar}$ およびフィッション トラック年代. 地質雑, $100(10), 787-798$. 